\title{
Pendampingan Guru Melalui Capacity Building dalam Rangka Optimalisasi Implementasi Penilaian Otentik Kurikulum 2013 (K-13) di MINU Curungrejo Kepanjen Malang
}

\author{
Nanik Ulfa, Aan Fardani Ubaidillah, Isna Nurul Inayati \\ Universitas Islam Raden Rahmat Malang \\ nanikulfaunira@gmail.com, afubaidillah@gmail.com,tsani_kids@yahoo.com
}

\begin{tabular}{|c|c|c|c|c|}
\hline Received & Jan 11 th 2019 & Revised & Marc 11 th 2019 & May $6^{\text {th }} 2019$ \\
\hline
\end{tabular}

\begin{abstract}
Kurikulum 2013's is actually a government program that has been rolled out since then. However, in practice, there are still many teachers who have difficulties to implement it, especially in the case of the implementation of authentic assessments. This was experienced by the teachers of MINU Curungrejo Kepanjen Malang Regency. On this basis, the program focused on helping a teacher to improve understanding of Curriculum 2013 implementation (K-13) that relates to assessment. Various assessments must be carried out, namely; optical assessment, assessment of learning outcomes, Assessment of mastery learning, class assessment, and attitude assessment. The community service method in this activity uses two phases; the School Action Research and the Outcome Mapping. The results of the activities were carried out for six weeks starting from August to September 2018. They showed that intensive training and mentoring through School Action Research (SAR) and Outcome Mapping (OM) can improve the ability of teachers to implement the 2013 curriculum.
\end{abstract}

Keywords: Teacher Competence, Authentic Assessment, The Curriculum 2013's (K-13), School Action Research, Outcome Mapping.

\section{Pendahuluan}

Kurikulum dan perubahannya merupakan hal yang tidak dapat dipisahkan, karena perubahan kurikulum merupakan suatu tuntutan yang harus dilakukan untuk memperbaiki proses pendidikan. ${ }^{1}$ Pendidikan menjadi kebutuhan yang mendasar bagi seseorang untuk memperbaiki sikap dan pola pikir dalam hidupnya. Sistem dan pola pendidikan yang baik dapat terwujud dengan kurikulum yang baik ${ }^{2}$. Peralihan pada kurikulum yang baru dan yang lebih baik, tentunya akan melibatkan banyak komponen. Waktu yang dibutuhkan untuk penyesuaian juga tidak singkat, begitu juga dana yang dibutuhkan juga sangat besar. Pelaksanaan kurikulum 2013 yang secara serempak dilaksanakan pada tahun 2014 pada jenjang pendidikan dasar sebenarnya sedikit dapat mengurangi beban para guru dari pekerjaan yang sifatnya administratif ${ }^{3}$. Pada pelaksanaan

\footnotetext{
${ }^{1}$ Yin Cheong Cheng, "Effectiveness of Curriculum Change in School: An Organizational Perspective," International Journal of Educational Management 8, no. 3 (June 1, 1994): 26-34; Margarida Lucas and Isabel Cabrita, "The Implications of Curriculum Change: Perceptions of East Timorese Policymakers," The Asia-Pacific Education Researcher 25, no. 5 (December 1, 2016): 807-815.

2 Imas Kurniasih and Berlin Sani, Revisi Kurikulum 2013 (Jakarta: Kata Pena, 2016), iii.

${ }^{3}$ Mulyasa Enco, Menjadi Guru Profesional (Bandung: Remaja Rosdakarya, 2003), 3.
}

Volume 3, Number 1, Mei 2019|32

Capacity Building Guru MINU Curung Rejo Kepanjen Malang dalam Implementasi Penilaian Otentik Kurikulum 2013 (K-13) 
kurikulum 2013 ini guru tidak lagi dituntut untuk menjabarkan Kompetensi dasar ke dalam Indikator Hasil Belajar, dan juga membuat silabus. ${ }^{4}$ Namun demikian dengan permasalahan baru bermunculan, salah satu dari sekian masalah yang baru tersebut adalah ketidaksiapan guru dalam pelaksanaan kurikulum 2013. ${ }^{5}$ Dengan ketidaksiapan guru dalam pelaksanaan kurikulum 2013, tidak sedikit sekolah yang menerapkan kurikulum 2013, namun pelaksanaannya tetap KTSP 2006. Hal ini mengakibatkan guru kesulitan ketika dihadapkan dengan penilaian. Penilaian pada kurikulum 2013 mencakup 3 komponen, yaitu sikap spiritual (KI-1), sosial (KI-2), pengetahuan (KI-3) dan keterampilan (KI-4) yang cukup kompleks acapkali menjadi kendala bagi guru ketika akan membuat laporan hasil belajar.

Dalam kondisi yang demikian, sesungguhnya Kepala Sekolah/Madrasah menjadi sosok terdepan yang memiliki tanggung jawab untuk mengupayakan berbagai langkah perbaikan yang diperlukan. Sebagai “Guru yang diberi Tugas Tambahan” langkah tersebut selain merupakan upaya Kepala Sekolah/Madrasah dalam menyelesaikan berbagai persoalan di sekolah, sekaligus merupakan wahana pengembangan profesi berkelanjutan sebagaimana diamanatkan dalam Peraturan Menteri Pendidikan dan Kebudayaan Nomor 6 tahun 2018 tentang Penugasan Guru sebagai Kepala Sekolah ${ }^{6,7}$. Lingkup persoalan yang perlu didiagnosa dan selanjutnya diperbaiki mengacu pada delapan standar yang sebagaimana termuat dalam Peraturan Pemerintah Republik Indonesia Nomor 19 Tahun 2005 tentang Standar Nasional Pendidikan

Salah satu upaya yang dapat dilakukan adalah dengan melaksanan Penelitian Tindakan Sekolah (School Action Research) dengan berbagai jenis dan modelnya. Isu ini yang ditawarkan oleh Tim Pelaksana Kegiatan Pengabdian Masyarakat pada saat menginisiasi kegiatan pengabdian masyarakat di Madrasah Ibtidaiyah Nahdlatul Ulama (MINU) Curungrejo Kepanjen, Kabupaten Malang. Secara kolaboratif, tim pelaksana bersama-sama mengadakan diagnosa awal permasalahan

\footnotetext{
${ }^{4}$ Hari Setiadi, "Pelaksanaan Penilaian Pada Kurikulum 2013," Jurnal Penelitian dan Evaluasi Pendidikan 20, no. 2 (2016): 166-178.

${ }^{5}$ Beberapa kesulitan yang dihadapi guru dalam pelaksanaan Kurikulum 2013 bisa dilihat dalam Rifki Afandi, "Implementasi Kurikulum 2013 Dalam Mempersiapkan Sumber Daya Manusia Indonesia Menghadapi 'Masyarakat Ekonomi Asean'(Asean Economic Community) Pada 2015," in Prosiding Seminar Nasional Pendidikan: Tema "Implementasi Kurikulum, 2013; Ema Rahma Melati and Yuli Utanto, "Kendala Guru Sekolah Dasar Dalam Memahami Kurikulum 2013," Indonesian Journal of Curriculum and Educational Tecbnology Studies 4, no. 1 (2016): 1-9; Siti Halimah, “Analisis Pemahaman Dan Kesiapan Guru Mengimplementasikan Kurikulum 2013" (2015).

${ }^{6}$ Menteri Pendidikan dan Kebudayaan RI, Peraturan Menteri Pendidikan Dan Kebudayaan Republik Indonesia Nomor 6 Tabun 2018 Tentang Penugasan Guru Sebagai Kepala Sekolah, Bab VII Pengembangan Keprofesian Berkelanjutan Kepala Sekolah (Jakarta, 2018), 6, http://lppks.kemdikbud.go.id /uploads/pengumuman/1526355089Permendikbud_Nomor6_Tahun2018.pdf.

${ }^{7}$ Kompetensi Manajerial 2.6. bahwa Kepala Sekolah/Madrasah wajib memiliki kopetensi untuk mengelola guru dan staf dalam rangka pendayagunaan sumber daya manusia secara optimal. Lihat dalam Menteri Pendidikan Nasional RI, Peraturan Menteri Pendidikan Nasional Republik Indonesia Nomor 13 Tabun 2007 Tentang Standar Kepala Sekolab/Madrasab (Jakarta, 2007), 9, http://pmp.dikdasmen.kemdikbud.go.id / files/peraturan/permen/Permen_No_13_Tentang_Standar_Kepala_Sekolah.pdf.

8 Peraturan Pemerintah Republik. Indonesia Nomor 19 Tabun 2005 Tentang Standar Nasional Pendidikan (Jakarta, 2005).
} 
untuk mengotentifikasi dan mengkonfirmasi mengenai kapasitas guru MINU Curungrejo dalam mengimplementasikan penilaian otentik Kurikulum 2013 (K13). Diagnosa awal perlu dilakukan sebagai bagian dari analisis situasi untuk keperluan penyusunan rencana tindakan yang diperlukan. Diagnosa dilakukan selama dua minggu pada tanggal 6 sampai dengan 18 Agustus 2018 melalui pendekatan kuantitatif dalam bentuk pre-test mengenai Penilaian Otentik K13 serta melalui pendekatan kualitatif dengan teknik pengumpulan data wawancara mendalam bersama beberapa guru, serta analisis dokumen penilaian Guru, kemudian ditindaklanjuti dengan Focused Group Discussion (FGD) oleh Tim Pelaksana kegiatan Pengabdian Masyarakat bersama-sama dengan Kepala Madrasah dan Guru MINU Curungrejo.

Diagnosa awal dilakukan melalui pre-test yang dilakukan pada tanggal 6 Agustus 2018 terdiri atas 30 soal pilihan ganda tentang implementasi penilaian otentik. Struktur soal terdiri dari: 10 soal untuk penilaian aspek sikap, 10 soal untuk penilaian aspek pengetahuan, dan 10 soal untuk penilaian aspek keterampilan. Hasil pre-test menunjukkan bahwa dua orang Guru memiliki kemampuan yang baik (rata-rata skor 85) dalam pemahaman dan kemampuan melaksanakan penilaian otentik, tujuh orang memiliki pemahaman dan kemampuan pada taraf cukup (skor 65), sisanya sebanyak 5 orang masih kurang (rata-rata skor 50). Jika dirata-rata, total kemampuan guru masih berada pada level cukup (rata-rata skor 66,7$)^{9}$. Hal ini tentu belum ideal untuk memenuhi lima karakteristik penilaian dalam K13 ${ }^{10,11,12}$. Data-data tersebut kemudian dielaborasi melalui pendekatan kualitatif dengan teknik wawancara mendalam dan analisis dokumen.

Melalui wawancara mendalam bersama para Guru didapatkan peta permasalahan antara lain: (1) Guru, terutama yang senior/berusia paruh baya mengalami kesulitan mengembangkan penilaian otentik K13 karena kompleksitas aspek yang harus diisi, di tengah tugas administrasi kepengajaran lain yang juga harus dilakukan ${ }^{13}$, (2) beberapa Guru hanya melakukan satu dan maksimal 2 teknik penilaian pada masing-masing domain afektif, kognitif, dan psikomotor. Dari ragam yang muncul, observasi, tes tulis (tes obyektif, essai, dan urian singkat), penugasan, tes

\footnotetext{
${ }^{9}$ Hasil pre-test melalui tes tulis pada 14 orang Guru MINU Curungrejo pada tanggal 6 Agustus 2018.

${ }^{10}$ Lima karakteristik yang dimaksud mencakup: (1) Belajar Tuntas, (2) Otentik, (3) Berkesinambungan, (4) Berdasarkan Acuan Kriteria, dan (5) Menggunakan Teknik Penilaian yang Bervariasi. Lebih lanjut lihat dalam Kementerian Pendidikan dan Kebudayaan, Panduan Teknik Penilaian Di Sekolah Dasar (Jakarta: Kementerian Pendidikan dan Kebudayaan, 2013), 5-6.
"Penilaian
2013,"
vol.
1
2014, 1-15,

Alimuddin,

Dalam Kurikulum

https://journal.uncp.ac.id/index.php/proceding/article/view/220/209.

12 Wuri Wuryani and Muhhammad Irham, "Penilaian Dalam Perspektif Kurikulum 2013” 19, no. 1 (2009): 181-199.

13 Triangulasi Hasil Wawancara dengan Guru MINU Curungrejo atas nama Wiji Kusnul Chotimah (6 Agustus 2018), Atik Anwariyati (8 Austus 2018), Arifin (8 Agustus 2018), Muhammad Riadi (10 Agustus 2018).
} 
praktik, dan portofolio mendominasi karena ketiganya paling mudah dilakukan ${ }^{14}$. Adapun berkenaan dengan varian teknik penilaian lain seperti penilaian diri, penilaian antar peserta didik dan jurnal (domain afektif); varian tes tulis berbentuk menjodohkan, sambung kata, analisis paragraf (domain kognitif); serta penilaian proyek (domain psikomotorik), dari 14 orang guru, hanya dua orang $(2,55)$ yakni Kepala Madrasah dan seorang guru yang telah berstatus PNS (Pegawai Negeri Sipil) yang mampu melakukan hampir 80\% varian teknik penilaian pada tiap domain ${ }^{15}$.

Pada prinsipnya tujuan dari sebuah penilaian adalah sebuah formatif (membentuk karakter dan perilaku, menjadikan peserta didik sebagai pembelajar sepanjang hayat), diagnostik (melihat perkembangan peserta didik dan feed-back-koreksi pembelajaran dan mengukur capaian agar dapat dilakukan hasil pembelajaran ${ }^{16}$. Artinya bahwa kesesuaian (validitas dan reliabilitas) teknik penilaian yang dikembangkan dalam konteks K13 berkaitan erat dengan otentisitas capaian belajar peserta didik yang dapat dilaporkan dan diberikan penghargaan. Oleh karenanya, temuan diagnosa awal sebagaimana diuraikan di atas, menjadi dasar bagi tim Pelaksana kegiatan Pengabdian Masyarakat ini untuk merancang kegiatan tindak lanjut perbaikan yang dilakukan. Melalui Focused Group Discussion, maka disepakati bahwa para guru perlu pendampingan dalam implementasi penilaian otentik Kurikulum 2013 (K13).

\section{Metode}

Metode yang digunakan dalam kegiatan ini memadukan antara Penelitian Tindakan Sekolah (School Acton Research)/PTS sebagai wahana perbaikan terhadap situasi awal mitra program (MINU Curungrejo, Kepanjen, Malang). Kemudian langkah tindak lanjut dilakukan melalui metode outcome mapping (OM). Metode PTS menggunakan jenis simultan terintegrasi dengan Model Action Researh dari Mc.Kernan yang mencakup tujuh langkah pada tiap siklusnya yakni: (1) Analisis Situasi (Reconaiscance)/Kenal Medan, (2) Perumusan dan Klarifikasi Permasalahan, (3) Hipotesis Tindakan, (4) Perencanaan Tindakan, (5) Penerapan Tindakan dan Monitoring, (6) Evaluasi Hasil

\footnotetext{
${ }^{14}$ Triangulasi Hasil Wawancara dengan Guru MINU Curungrejo atas nama Dyah Wulandari (6 Agustus 2018), Puji Rahayu (9 Austus 2018), Arifin (8 Agustus 2018), Muhammad Riadi (10 Agustus 2018), Faiza Akhlaqul Karimah (10 Agustus 2018), Rohman Nur Alfan (11 Agustus 2018) dan Kepala MINU Curungrejo atas nama Amin (6 dan 11 Agustus 2018).

${ }^{15}$ Hasil analisis dokumen penilaian hasil belajar Guru MINU Curungrejo mulai 10 Agustus 2018 sampai dengan 18 Agustus 2018). Dalam analisis tersebut, hanya dokumen atas nama Amin (Kepala Madrasah) dan Dyah Wulandari (Guru berstatus PNS) yang mencapai varian hampir $80 \%$ dari berbagai ragam penilaian otentik di tiap domain (Afektif, Kognitif, dan Psikomotorik).

${ }_{16}$ Kurniasih and Sani, Revisi Kurikulum 2013, 3.
} 
Tindakan, (7) Refleksi dan Pengambilan Keputusan untuk pengembangan selanjutnya ${ }^{17}$. PTS dilakukan sebanyak dua siklus selama dua minggu mulai 20 Agustus 2018 hingga 29 Agustus 2018. Tiap siklus terdiri atas dua kali pertemuan untuk penyampaian materi dan satu kali untuk post-test pertama, sementara dua pertemuan awal pada siklus kedua berfokus pada praktik langsung melalui pembimbingan lapangan, dan satu pertemuan sisa dilaksanakan untuk post-tes kedua. Gambaran mengenai langkah-langkah PTS yang dilakukan, disajikan pada Gambar 1.

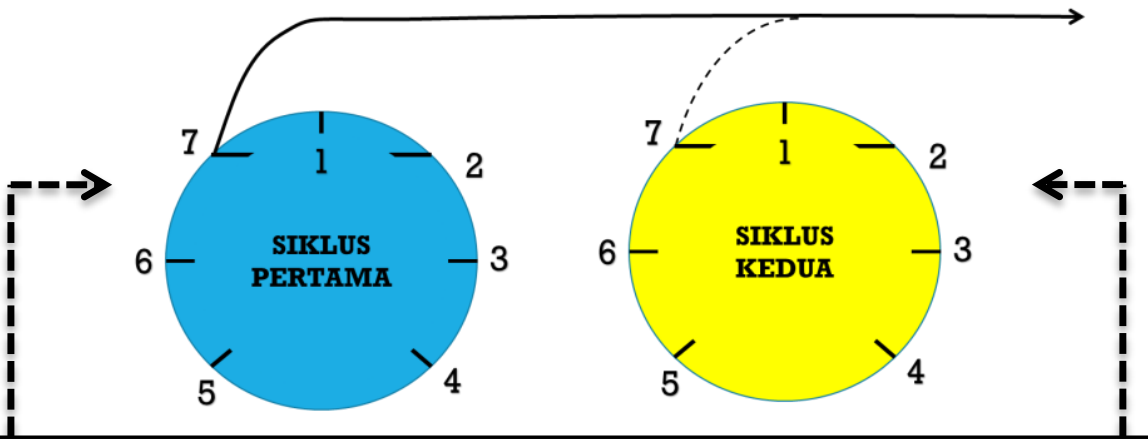

Keterangan:

1. Analisis Situasi (Reconaiscance)/Kenal Medan,

2. Perumusan dan Klarifikasi Permasalahan,

3. Hipotesis Tindakan,

4. Perencanaan Tindakan,

5. Penerapan Tindakan dan Monitoring,

6. Evaluasi Hasil Tindakan,

7. Refleksi dan Pengambilan Keputusan untk Pengembangan Selanjutnya

Gambar 1. Langkah-Langkah Penelitian Tindakan Sekolah dalam Capacity Building Guru MINU Curungrejo Kepanjen Malang dalam Pelaksanaan Penilaian Otentik Kurikulum 2013 (K-13).

Setelah tahap akhir PTS yakni Refleksi dan Pengambilan Keputusan untuk pengembangan selanjutnya ditindaklanjuti melalui metode OM, yakni langkah kerja yang berorientasi pada perubahan perilaku aktor, interaksi antar aktor, dan pemetaan kemajuan ${ }^{18}$. OM dibagi menjai tiga tahap, yaitu: (1) rancangan terarah, dalam tahap ini merencanakan strategi yang akan digunakan; (2) monitoring capaian dan kinerja, tahap kedua ini memberikan kerangka untuk memantau kegiatan yang sedang berlangsung; (3) perencanaan evaluasi, tahap ini membantu program untuk mengidentifikasi prioritas evaluasi dan mengembangkan rencana evaluasi. Untuk lebih singkatnya outcome mapping ini berfokus pada perubahan tingkah laku, monitoring secara intensif dan evaluasi

17 Yoyok Soesatyo, "Pelatihan Penulisan Proposal Penelitian Tindakan Kelas (PTK) Bagi Guru Ekonomi Kabupaten Sidoarjo | Jurnal Pemberdayaan Masyarakat Madani (JPMM)” 1, no. 2 (2017): 162-178.

18 Steff Defrez, Outcome Mapping: Jejak Perubahan Menuju Keberbasilan (Denpasar: PT. Cintya, 2010), 1.

Volume 3, Number 1, Mei 2019|36

Capacity Building Guru MINU Curung Rejo Kepanjen Malang dalam Implementasi Penilaian Otentik 
disetiap item program. Keseluruhan tahapan dalam OM dilaksanakan selama dua minggu mulai tanggal 3 hingga 15 September 2018, dengan tiga langkah yang meliputi: (1) Pembuatan Rancangan Terarah (mencakup penetapan: visi, misi, mitra, capaian, penanda kemajuan, strategi, dan perilaku organisasi dari kegiatan capacity building), (2) Proses Monitoring (mencakup penetapan: priotitas monitoring, jurnal capaian, jurnal strategi, dan jurnal kinerja), dan (3) Penyusunan Rencana Evaluasi (mencakup penetapan: strategi dan pelaksanaan Evaluasi Akhir).

\section{Hasil dan Diskusi}

Madrasah Ibtidaiyah Nahdlatul Ulama (MINU) Curungrejo adalah sebuah Madrasah swasta yang berlokasi di Jalan Raya Curungrejo, Desa Jenggolo Kecamatan Kepanjen Kabupaten Malang. Pada tahun ajaran 2018/2019, MINU Curungrejo tercatat memiliki 14 orang tenaga pendidik (termasuk Kepala Madrasah) dimana salah seorang diantaranya berstatus sebagai Pegawai Negeri Sipil (PNS). Kegiatan pengabdian dilaksanakan menjadi dua tahap, tahap pertama berupa kegiatan pembinaan dan pendampingan melalui metode Penelitian Tindakan Sekolah (Classroom Action Research)/PTS, tahap kedua sekaligus sebagai tindaklanjut kegiatan, dilakukan dalam bentuk pendampingan penuh melalui metode Outcome Mapping/OM. Empat langkah awal sebagai bagian dari tahap pertama melalui metode PTS yakni: (1) Analisis Situasi (Reconaiscance)/Kenal Medan, (2) Perumusan dan Klarifikasi Permasalahan, (3) Hipotesis Tindakan, dan (4) Perencanaan Tindakan, adalah kegiatan preliminary study guna melakukan diagnosa awal. Kegiatan ini dilakukan selama dua minggu kerja mulai tanggal 6 Agustus 2018 hingga tanggal 18 Agustus 2018.

Hasil diagnosa awal menunjukkan bahwa secara umum, kemampuan Guru MINU Curungrejo dalam mengimplementasikan Penilaian Otentik Kurikulum 2013 (K13) berada pada level cukup. Hal ini diketahui dari rata-rata hasil pre-test dari 14 orang Guru, dimana kemampuan awal yang diraih berada pada skor 66,7. Setelah melakukan elaborasi melalui wawancara mendalam, analisis dokumen dan Focused Group Discussion (FGD) maka diputuskan untuk diadakan kegiatan Capacity Building bagi guru MINU. Kegiatan ini selanjutnya masuk dalam kegiatan ke 5, 6, dan 7 dalam siklus Action Research yang dalam PTS ini mengadopsi dari Model Mc. Kernan. Ketiga kegiatan tersebut mencakup: Penerapan Tindakan dan Monitoring, Evaluasi Hasil Tindakan, dan Refleksi dan Pengambilan Keputusan untuk Pengembangan Selanjutnya.

Ketujuh kegiatan dalam tahap pertama PTS tersebut dilakukan sebanyak dua siklus, dimana tiap siklusnya terdiri atas tiga pertemuan. Pada siklus pertama, dua pertemuan awal dilakukan untuk 
memberi materi melalui pelatihan dan diakhiri post-test. Adapun pada siklus kedua, dua pertemuan awal dilakukan dalam bentuk pendampingan dan diakhiri post-test kedua, sekaligus tes akhir pada pertemuan ketiga. Hasil kegiatan pada tahap pertama (PTS) menunjukkan adanya peningkatan kemampuan dari rata-rata 66,7 (predikat cukup) pada Pra-Siklus menjadi 68,9 (predikat cukup) pada Siklus 1 dan naik menjadi 78,4 (predikat baik) pada Siklus 2. Secara lebih lengkap, rekam peningkatan kemampuan guru sebelum mengikuti pelatihan dan pendampingan pada tahap pertama (PTS) kegiatan pengabdian ini disajikan pada Tabel 1.

\section{Tabel 1.}

Perbandingan Kemampuan Guru antar Siklus pada Tahap PTS

\begin{tabular}{llllcccc}
\hline No. & $\begin{array}{c}\text { Nama Guru } \\
\text { (Inisial) }\end{array}$ & $\begin{array}{c}\text { Hasil } \\
\text { Pre-Test }\end{array}$ & Predikat & $\begin{array}{c}\text { Hasil } \\
\text { Post-Test } \\
\text { Siklus } 1\end{array}$ & Predikat & $\begin{array}{c}\text { Hasil } \\
\text { Post-Test } \\
\text { Siklus 2 }\end{array}$ & Predikat \\
\hline 1. & Am. & 80 & Baik & 85 & Baik & 90 & Sangat Baik \\
\hline 2. & Ar. & 65 & Cukup & 70 & Baik & 80 & Baik \\
\hline 3. & AA. & 65 & Cukup & 69 & Cukup & 75 & Baik \\
\hline 4. & DRM. & 65 & Cukup & 68 & Cukup & 75 & Baik \\
\hline 5. & DW. & 95 & Sangat Baik & 95 & Sangat Baik & 97 & Sangat Baik \\
\hline 6. & FAK. & 65 & Cukup & 70 & Baik & 85 & Baik \\
\hline 7. & IDW. & 55 & Kurang & 60 & Cukup & 75 & Baik \\
\hline 8. & LM. & 65 & Cukup & 70 & Baik & 80 & Baik \\
\hline 9. & MR. & 50 & Kurang & 60 & Cukup & 78 & Baik \\
\hline 10. & NM. & 65 & Cukup & 68 & Cukup & 78 & Baik \\
\hline 11. & PR. & 45 & Kurang & 55 & Kurang & 65 & Cukup \\
\hline 12. & RNA. & 65 & Cukup & 70 & Baik & 75 & Baik \\
\hline 13. & WKC. & 45 & Kurang & 60 & Cukup & 70 & Baik \\
\hline 14. & YENS. & 55 & Kurang & 65 & Cukup & 75 & Baik \\
\hline \hline Rata-Rata Kelas & 66,7 & Cukup & 68,9 & Cukup & 78,4 & Baik \\
\hline
\end{tabular}

Kegiatan capacity building melalui PTS sebagaimana disajikan hasilnya pada Tabel 1 menunjukkan bahwa skema PTS dimana tindakannya berupa pelatihan dan pendampingan terbukti efektik meningkatkan kemampuan Guru MINU Curungrejo dalam implementasi K13. Selanjutnya, untuk menunjang keberlanjutan implementasi penilaian otentik K13 oleh para peserta, tim pelaksana melakukan kegiatan tahap dua melalui metode Outcome Mapping/OM. Kegiatan ini sekaligus merupakan tindak lanjut dari fase akhir PTS model Mc.Kernan yakni Refleksi dan Pengambilan Keputusan untuk Pengembangan Selanjutnya. Kegiatan ini dilakukan selama dua minggu kerja mulai 3 September hingga 15 September 2018.

Sesuai dengan rencana yang telah dibuat melalui FGD bersama Kepala Madrasah dan jajaran Guru MINU Curungrejo yang menjadi peserta pelatihan, Keseluruhan kagiatan dalam OM 
dilaksanakan selama dua minggu mulai tanggal 3 hingga 15 September 2018, dengan tiga langkah yang meliputi: (1) Pembuatan Rancangan Terarah (mencakup penetapan: visi, misi, mitra, capaian, penanda kemajuan, strategi, dan perilaku organisasi dari kegiatan capacity building), (2) Proses Monitoring (mencakup penetapan: prioritas monitoring, jurnal capaian, jurnal strategi, dan jurnal kinerja), dan (3) Penyusunan Rencana Evaluasi (mencakup penetapan: strategi dan pelaksanaan Evaluasi Akhir). Implementasi OM sebagai tahap kedua dalam kegiatan ini disajikan pada Gambar 2.

\begin{tabular}{|c|c|c|c|c|c|}
\hline & \multicolumn{5}{|c|}{ Rancangan Terarah } \\
\hline & \multicolumn{2}{|c|}{ Visi } & \multicolumn{3}{|c|}{ Meningkatkan kompetensi guru dalam pelaksanaan K-13 } \\
\hline & \multicolumn{2}{|l|}{ Misi } & \multicolumn{3}{|c|}{$\begin{array}{l}\text { Memberikan informasi dan pendampingan program K-13 kepada guru MI } \\
\text { Curungrejo }\end{array}$} \\
\hline & \multicolumn{2}{|c|}{ Mitra } & \multicolumn{3}{|c|}{ Guru MI Curungrejo } \\
\hline & \multicolumn{2}{|c|}{ Capaian } & \multicolumn{3}{|c|}{ Dapat melaksanakan proses penilaian $\mathrm{K}-13$ dengan proses secara sistematis } \\
\hline rer & \multicolumn{2}{|c|}{$\begin{array}{l}\text { Penanda } \\
\text { kemajuan }\end{array}$} & \multicolumn{3}{|c|}{$\begin{array}{l}\text { 1. Memahami KI-1/ KI-2/KI-3/KI-4 } \\
\text { 2. Mengerti tahapan penilaian KI-1/ KI-2/KI-3/KI-4 } \\
\text { 3. Mengerti instrumen masing-masing penilaian }\end{array}$} \\
\hline & \multicolumn{2}{|c|}{ Strategi } & \multicolumn{3}{|c|}{ Direct Learning, praktik terbimbing dan Brainstorming } \\
\hline & \multicolumn{2}{|c|}{$\begin{array}{l}\text { Perilaku } \\
\text { Organisasi }\end{array}$} & \multicolumn{3}{|c|}{$\begin{array}{l}\text { Menguji pemahaman dengan praktek analisis KD dan membuat instrumen } \\
\text { penilaian }\end{array}$} \\
\hline \multicolumn{4}{|c|}{ Proses Monitoring } & \multicolumn{2}{|c|}{ Rencana Evaluasi } \\
\hline \multicolumn{2}{|c|}{$\begin{array}{l}\text { Prioritas } \\
\text { Monitoring }\end{array}$} & \multicolumn{2}{|c|}{$\begin{array}{l}\text { Mengumpulkan informasi terkait } \\
\text { permasalahan yang muncul/ dihadapi oleh } \\
\text { Guru MI Curungrejo }\end{array}$} & \multirow{4}{*}{$\begin{array}{l}\text { Strategi } \\
\text { dan } \\
\text { Pelaksana } \\
\text { an } \\
\text { Evaluasi }\end{array}$} & \multirow{4}{*}{$\begin{array}{l}\text { Menggunakan pendekatan proses } \\
\text { dengan analisis hasil perkembangan } \\
\text { kemampuan guru selama kegiatan } \\
\text { yang ditunjukkan oleh luaran- } \\
\text { luaran hasil praktek sebagaimana } \\
\text { yang tercatat pada jurnal. } \\
\text { Penilaian kemampuan akhir } \\
\text { sekaligus tindak lanjut dilakukan } \\
\text { melalui Focused Group Discussion } \\
\text { dengan kepala Madrasah }\end{array}$} \\
\hline $\begin{array}{l}\text { Jurnal } \\
\text { capaia }\end{array}$ & & \multicolumn{2}{|c|}{$\begin{array}{l}\text { Mengumpulkan data tentang capaian hasil } \\
\text { belajar/ praktek }\end{array}$} & & \\
\hline \multicolumn{2}{|c|}{$\begin{array}{l}\text { Jurnal } \\
\text { strategi }\end{array}$} & \multicolumn{2}{|c|}{$\begin{array}{l}\text { Mengumpulkan data tentang kesulitan } \\
\text { yang dialami guru dalam menyusun } \\
\text { instrumen penilaian }\end{array}$} & & \\
\hline \multicolumn{2}{|c|}{ Jurnal kinerja } & \multicolumn{2}{|c|}{$\begin{array}{l}\text { Mengumpulkan data tentang luaran akhir } \\
\text { hasil belajar/ praktek dari seluruh guru, } \\
\text { sesuai tagihan yang ditetapkan }\end{array}$} & & \\
\hline
\end{tabular}

Gambar 2. Implementasi Outcome Mapping dalam Capacity Building Guru MINU Curungrejo Kepanjen Malang dalam Pelaksanaan Penilaian Otentik Kurikulum 2013 (K-13).

Berdasarkan keseluruhan tahapan OM yang telah dilakukan, didapatkan hasil bahwa setelah mengikuti pelatihan dan pendampingan, mayoritas guru (10 orang dari 14 orang) telah mampu mengimplementasikan $80 \%$ varian teknik penilaian otentik, baik dari penilaian afektif, kognitif, maupun psikomotorik. Sisanya sebanyak 4 orang guru baru dapat mengimplementasikan pada taraf 75\% dari teknik penilaian otentik. Dari konfirmasi yang tim lakukan pada FGD akhir, seluruh 
peserta $(100 \%)$ sepakat bahwa unsur kegiatan pendampingan intensif lebih dominan memberi kontribusi dalam membantu guru untuk lebih mudah dalam menyusun dan melaporkan penilaian otentik K13, dibanding pada saat sesi materi (pertemuan pertama dan kedua pada Siklus 1 tahap pertama kegiatan/PTS).

Kompetensi guru sebagaimana diamanatkan dalam Undang-Undang Republik Indonesia Nomor 14 Tahun 2005 tentang Guru dan Dosen mencakup empat kompetensi, yakni: Pedagogik, Profesional, Personal, dan Sosial ${ }^{19}$. Kemampuan guru dalam mengadakan penilaian hasil belajar sesungguhnya termasuk dalam Kompetensi Pedagogik ${ }^{20}$. Nampaknya, temuan Tim Pelaksana Kegiatan Pengabdian Masyarakat terkait problem awal yang dihadapi oleh Guru MINU Curungrejo, identik dengan kendala umum yang dialami guru di berbagai daerah. Beberapa hasil penelitian menunjukkan bahwa rata-rata dalam pelaksanaan penilaian otentik K13, guru mengalami kendala-kendala berupa: kompleksitas penilaian, menguras waktu, dan keadaan siswa yang kurang mendukung ${ }^{21}$, kurangnya pemahaman, rendahnya kreativitas guru, dan kurangnya pelatihan ${ }^{22}$.

Berkenaan dengan problematika yang dihadapi guru dalam mengembangkan dan melaksanakan penilaian hasil belajar, khususnya penilaian otentik K13, seungguhnya ada banyak wahana problem solver yang bisa dilakukan. Pelatihan dan pendampingan diantaranya, merupakan salah satu cara yang terbukti mampu menyelesaikan persoalan tersebut ${ }^{23}$. Dari tinjauan penelitian misalnya, beberapa penelitian juga menunjukkan bahwa program pendampingan kurikulum juga mampu menghasilkan produk implementasi K13 yang baik ${ }^{24}$. Ulasan-ulasan tersebut memberikan penguatan bahwa aneka ragam kegiatan pelatihan dan pendampingan dengan berbagai metode, dapat senantiasa digalakkan dalam memecahkan berbagai persoalan mengenai implementasi

19 Undang-Undang Republik Indonesia Nomor 14 Tahun 2005 tentang Guru dan Dosen. http://luk.staff.ugm.ac.id/atur/UU14-2005GuruDosen.pdf.

${ }^{20}$ Lihat Suprananto. “Kompetensi Pendidik dalam Bidang Penilaian”. Prosiding: Seminar Nasional Evaluasi Pendidikan SNEP II (2014):1-6. https://conf.unnes.ac.id/index.php/snep/II/paper/viewFile/161/52.

${ }^{21}$ Lihat Yayuk Nur Rohmani Dewi. "Problematika Guru dalam Menerapkan Penilaian Autentik pada Kurikulum 2013 di SD Negeri Bayan No. 216 Surakarta", Naskah Publikasi Ilmiah. (Surakarta: Fakultas Keguruan dan Ilmu Pendidikan Universitas Muhammadiyah Surakarta, 2017), 1-17. http://eprints.ums.ac.id/52532/11/NASKAH\%20PUBLIKASI\%20ILMIAH.pdf.

22 Disamping menemukan problematika yang identik dengan Penelitian Yayuk Nur Rohmani Dewi, ketiga Problematika kurangnya pemahaman, rendahnya kreativitas guru, dan kurangnya pelatihan sebagaimana disebutkan ditemukan oleh Enggarwati dalam penelitiannya di SD Negeri Glagah. Lebih lanjut lihat Nur Sasi Enggarwati, "Kesulitan Guru SD Negeri Glagah dalam Mengimplementasikan Penilaian Autentik pada Kurikulum 2013”. Naskah Publikasi. (Yogyakarta: Program Studi Pendidikan Guru Sekolah Dasar - Jurusan Pendidikan Prasekolah dan Sekolah Dasar -Fakultas Ilmu Pendidikan Universitas Negeri Yogyakarta, 2015), 1-10. http://journal.student.uny.ac.id/ojs/index.php/pgsd/article/viewFile/\%201141/1013.

${ }^{23}$ Lihat Hartini Kartini, et.al. "Pelatihan Penilaian Hasil Belajar Untuk Meningkatkan Kompetensi Profesional Guru". Abdimas Pedagogi, Volume 1 Nomor 1, Oktober (2107): 30-36. http://karya-ilmiah.um.ac.id/index.php/karya-dosen$\mathrm{fip} /$ article/viewFile/75985/4856

${ }^{24}$ Lihat hasil penelitian Irawan Ujiyono, "Evaluasi Program Pendampingan Implementasi Kurikulum 2013 Di Kabupaten Wonosobo".Media Manajemen Pendidikan, Volume $1 \quad$ No. $1 \quad$ Juni $2018 \quad$ (2018): 97-106. http://jurnal.ustjogja.ac.id/index.php/mmp/article/download/2883/1707 
kurikulum 2013 pada berbagai dimensinya, khususnya dalam penilaian otentik.

\section{Kesimpulan}

Kegiatan capacity building Guru MINU Curungrejo Kepanjen Malang dalam Implementasi Penilaian Otentik Kurikulum 2013 (K-13) mendapatkan sambutan dan apresiasi yang baik dari segenap civitas akademik di MINU Curungrejo. Capacity building yang dilakukan selama enam minggu mulai 6 Agustus 2018 hingga 15 September 2018 dengan tatap muka yang terjadwal selama dua tahap (tahan Penelitian Tindakan Sekolah dan Outcome Mapping/OM), terbukti dapat meningkatkan kemampuan guru dalam mengimplementasikan penilaian otentik kurikulum 2013 (K13). Peningkatan kemampuan dapat dilihat dari perkembangan peserta dimana pada saat diagnosa awal kemampuan rata-rata peserta berada pada predikta cukup (skor 66,7) meningkat menjadi berpredikat baik (skor 78,4) pada akhir kegiatan. Demikian halnya pada tahap 2 sebagai tindaklanjut yang dilakukan melalui metode OM, mayoritas guru (10 orang dari 14 orang) telah mampu mengimplementasikan $80 \%$ dan sisanya sebanyak 4 orang guru dapat mengimplementasikan pada taraf $75 \%$ dari teknik penilaian otentik.

Dari berbagai rangkaian kegiatan yang telah dilakukan, dapat direkomendasikan bahwa kegiatan pelatihan dan pendampingan yang sama dapat didiseminasikan pada sekolahsekolah/madrasah-madrasah lain pada berbagai jenjang. Adapun bagi MINU Curungrejo, kegiatan pelatihan dan pendampingan secara berjenjang dan berkala dapat dilakukan oleh pihak sekolah guna meningkatkan kapasitas guru dalam mengimplementasikan kompetensi kepribadian, sosial, dan profesional.

\section{Daftar Referensi}

Afandi, Rifki. "Implementasi Kurikulum 2013 Dalam Mempersiapkan Sumber Daya Manusia Indonesia Menghadapi ‘Masyarakat Ekonomi Asean'(Asean Economic Community) Pada 2015.” In Prosiding Seminar Nasional Pendidikan: Tema "Implementasi Kurikulum, 2013.

Alimuddin. "Penilaian Dalam Kurikulum 2013." Vol. 1, 2014. https://journal.uncp.ac.id/index.php/proceding/article/view/220/209.

Cheong Cheng, Yin. "Effectiveness of Curriculum Change in School: An Organizational Perspective." International Journal of Educational Management 8, no. 3 (June 1, 1994): 26-34.

Defrez, Steff. Outcome Mapping: Jejak Perubahan Menuju Keberbasilan. Denpasar: PT. Cintya, 2010. 
Enco, Mulyasa. Menjadi Guru Profesional. Bandung: Remaja Rosdakarya, 2003.

Halimah, Siti. “Analisis Pemahaman Dan Kesiapan Guru Mengimplementasikan Kurikulum 2013” (2015).

Kementerian Pendidikan dan Kebudayaan. Panduan Teknik Penilaian Di Sekolah Dasar. Jakarta: Kementerian Pendidikan dan Kebudayaan, 2013.

Kurniasih, Imas, and Berlin Sani. Revisi Kurikulum 2013. Jakarta: Kata Pena, 2016.

Lucas, Margarida, and Isabel Cabrita. "The Implications of Curriculum Change: Perceptions of East Timorese Policymakers." The Asia-Pacific Education Researcher 25, no. 5 (December 1, 2016): 807-815.

Melati, Ema Rahma, and Yuli Utanto. "Kendala Guru Sekolah Dasar Dalam Memahami Kurikulum 2013." Indonesian Journal of Curriculum and Educational Technology Studies 4, no. 1 (2016): 1-9.

Menteri Pendidikan dan Kebudayaan RI. Peraturan Menteri Pendidikan Dan Kebudayaan Republik Indonesia Nomor 6 Tabun 2018 Tentang Penugasan Guru Sebagai Kepala Sekolah, Bab VII Pengembangan Keprofesian Berkelanjutan Kepala Sekolab. Jakarta, 2018. http://lppks.kemdikbud.go.id /uploads/pengumuman/1526355089Permendikbud_Nomor6_Tahun2018.pdf.

Menteri Pendidikan Nasional RI. Peraturan Menteri Pendidikan Nasional Republik Indonesia Nomor 13 Tabun 2007 Tentang Standar Kepala Sekolah/Madrasah. Jakarta, 2007. http://pmp.dikdasmen.kemdikbud.go.id /files/peraturan/permen/Permen_No_13_Tentang_Standar_Kepala_Sekolah.pdf.

Setiadi, Hari. "Pelaksanaan Penilaian Pada Kurikulum 2013." Jurnal Penelitian dan Evaluasi Pendidikan 20, no. 2 (2016): 166-178.

Soesatyo, Yoyok. "Pelatihan Penulisan Proposal Penelitian Tindakan Kelas (PTK) Bagi Guru Ekonomi Kabupaten Sidoarjo | Jurnal Pemberdayaan Masyarakat Madani (JPMM)" 1, no. 2 (2017): 162-178.

Wuryani, Wuri, and Muhhammad Irham. "Penilaian Dalam Perspektif Kurikulum 2013" 19, no. 1 (2009): 181-199.

Peraturan Pemerintah Republik Indonesia Nomor 19 Tabun 2005 Tentang Standar Nasional Pendidikan. Jakarta, 2005. 